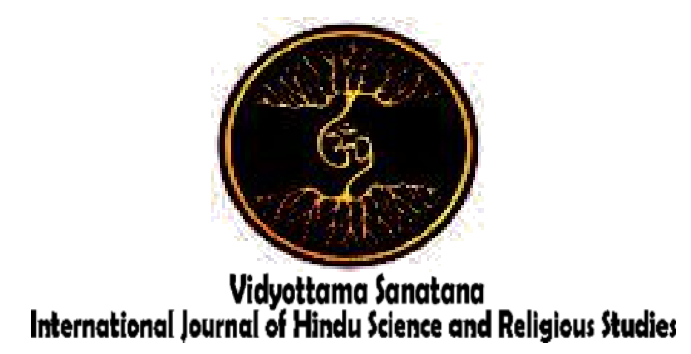

Vol. 2 No. 1 May 2018

\title{
The Perception Of Hindus In Denpasar City To The Abolition Of Sin In The Text Of Siva Puraana
}

\author{
By: \\ I Made Arsa Wiguna \\ Institut Hindu Dharma Negeri Denpasar \\ Email: arsa@ihdn.ac.id
}

\begin{abstract}
The aims of this paper are to describe the form of abolition of sin in the text of Siva Puraana, the comprehension of Hindus about Siva Puraana, as well as the perception of Hindus in Denpasar City about the abolition of sin in Siva Puraana. The word 'sin' in Hindu's terminology is well known as 'papa' which appeared and derived from asubha karma (bad behavior) of a human. Siva Puraana describes a lot of short holy texts (sloka) and stories about the abolition of sin by doing a devotion to the God Siva or by listening and reading the Siva Puraana text scripture. This research location was in Vrata Vijaya Ashram. The result of research, in general, was informant declared that sin couldn't be able to be wiped out, but the possible reason is equaling it by a good behaviour (subha karma), and also all the moral education in Siva Puraana should be understood and implemented in daily life, so human will be exempted from a sin.
\end{abstract}

Keywords: The Perception of Hindus, Abolition of Sin, the text of Siva Puraana

\section{Introduction}

Each of religious people should have a core of beliefs as a basis in order to actualize the religious life. Hinduism also has the core of beliefs known as Panca Sradha (five beliefs derive from Veda Sruti and Smrti). Two parts of Panca Sradha are Karmaphala and Punarbhava. Titib (2004: 281), declared as a basis of ethics and moral in Hinduism, Karmphala will influence the Punarbhava. 
Regarding Karmaphala, there are three types of Karmaphala, they are Sancita, Prarabda, and Kryamana.

Netra (2009: 29), explained that Sancita Karmaphala is the result of mankind behavior in the past which has not received or enjoyed yet and still become seeds that determine and influence the current life. Prarabda Karmaphala is a result of mankind behavior in this current life that has fully received or enjoyed. Kriyamana Karmaphala is a result of mankind behavior that has not received or enjoyed yet in this current life, so that it will be received in the future life.

Hindus believe that karma (act) determines the future life, while still alive or after the death. The basic of that beliefness is derive from Sarasamuccaya's scripture which declared that only karma (act) will be accompanying the Atman (soul in Hinduism terminology) to the last place (svarga or neraka, heaven or hell, but in Hinduism, the last purpose is the unity of Atman and Brahman called Moksha). Even though svarga and neraka are not stated explicitly in Panca Sradha, Hindus believe the existence of that places by the explanation in those texts, like Smrti such as Itihasa, Puraana, Slokantara, Sarasamuccaya and others.

Subha karma (good behavior) will deliver atman to the bright place (svarga), and the asubha karma (bad behavior) will deliver atman to the dark place called neraka. Asubha karma will arise a sin and influence the karma phala and punarbhava (cycle of birth repeatedly). This matter is also explained in Atma Prasangsa scripture, ie someone who loved to conduct a cockfighting, so that in the future life, he will be born as a rooster's food (Ginarsa, 2002: 23). Slokantara's scripture also describes the characteristic of birth from svarga and neraka. The existence of those texts that explain about sin caused by a bad behavior should ideally be used as guidelines by Hindus to protect the mind, words, and attitude as well. However, it is not immediately lead the Hindus not to do a bad attitude.

Actually, it is impossible to wipe out the sin or donate it to others. Mankind is responsible for their own sin. Apte (Titib, 2007: 260) explains that dosa or papa in English language is known as sin, in the Sanskrit language is known as papam, patakam, kalmasam. In Jawa Kuno (Old Javanese language), dosa means dosa, mistakes. Papa in Jawa Kuno language means dosa, bad habits, crime, mistakes, punishment/torture for sin. Apart from that, Hindu's literature only told about sin and the effect.

Manava Dharmasastra (VIII.381) declared that there is no bigger crime than killing Brahmana (part of Catur Varna who is learning Veda and leading a Yajna ceremonial), so don't ever think to do it (Pudja and Tjokorda Rai Sudharta, 1976: 515).

Slokantara (75-78), classified 4 types of sin ie: 1) Pataka (small sin), such as abortion, killing other people, ran the girl by force, married before the eldest brother or sister get married; 2) Upapataka (fair sin), such as killing the cow, killing the young girl, killing children, killing parents and older human, setting fire to the house with the owners; 3 ) Mahapataka (big sin), such as killing a Brahmana, drinking alcohol, stealing a gold, killing the teacher, raping a girl until die; 4) Atipataka (the biggest sin), such as raping the own daughter, own mother, breaking the holy or devotion place (Sudharta, 2003: 252-259). 
Bhagavadgita (XVI. 21), declares that kama (desire), krodha (anger), and lobha (greedy) are the three entrances to hell, and those should be avoided. However, in some Puraana, there is a different opinion about sin. A sinful human could be achieved and lived in God's places just because doing a good thing, for example, a thief who cleans up the Visnu temple to disappear his footprint there, and then after the death, he was picked up by Yama's troop (The Gods of death and justice in Hinduism), but finally on the way to Yama's place, Visnu's troop stop it and bring the soul of that thief to Vaikuntha (Gods Visnu place). Some of the stories in Puraana text have a similarity with Lubdaka story by Mpu Tanakung.

Siva Puraana as one of the eighteen Mahapuraana also describes the abolition of sin. It tells about Brahmana's wife who was sinful, while she was alive, got a good place in Gods Siva place (Kailash) just because she listened to Siva Puraana's reading session unintentionally. Siva Puraana is certainly believed a divine revelation directly from Gods Siva. There is a statement in one of Siva Puraana's sloka telling that "by reading several texts in Siva Puraana, then mankind will be free from any kind of sin, and the good people will getting lofty only by reading and listening to this holy Siva Puraana. Its gonna be the big question due to its impossible to wipe out the sin.

Reading Siva Puraana used to do in a special place like an ashram, and in this case, research location was located at Vrata Vijaya Ashram, Penatih, Denpasar City. This ashram was chosen because the reading activity of Siva Puraana text was conducted routinely and this ashram also devoted to Gods Siva and all the manifestation. The abolition of $\sin$ in
Siva Puraana is worth to study about in order not to doubt about sin's abolition. So that it made researcher feel the interest to study about Hindus perception about the abolition of sin in Siva Puraana's text.

There are three main cases in this research ie: 1) The form of abolition in Siva Puraana text; 2) The comprehension of Hindus in Denpasar City about Siva Puraana text; 3) The perception of Hindus in Denpasar City about the abolition of sin in Siva Puraana text.

\section{Methods}

This research location was in Vrata Vijaya Ashram, in Jl. Siulan Gg. Nusa Indah III No. 3. This ashram was chosen due to there is a reading session of Siva Puraana routinely every month and also devotion of Gods Siva and all the manifestation as well. The primary data resources were derived from informant related to the sin abolition in Siva Puraana and also the perception about it. The secondary data resources were gotten from journals, researchers, and literatures regarding this research's object.

Collecting data technique was also conducted by doing nonparticipant observation and deeply interview regarding this research topic to the management of Vrata Vijaya Ashram, devotee, students, and Hinduism academician in Denpasar City. Documentation study was also done, such as a gallery of the event in this ashram or linga as a devotion object. The research instrument was the researcher itself due to qualitative research. Analysis technique used was Miles and Huberman's model. 


\section{Result and Discussion}

\subsection{General Description of Research Location}

Vrata Vijaya Ashram was formally declare by Mahaguru Sri Jaya Nara on October $14^{\text {th }}, 2008$ and use the traditional architecture of Bali. This ashram was led by a spiritual teacher named Guru Sri Hasta Dala. Devotion in this ashram is especially directed to Gods Siva and the manifestation in the form of holy linggams (Gods Siva's symbol). Those holy linggams are: 1) Sri Karnath as the Gods Siva aspect to protect this universe; 2) Air Lingga as a place to beg a holy water from the Mother Nandini to sublime ourself; 3 Sri Nandini as Gods Siva aspect which gives a prosperous to the mankind; 4) Lingga Guru functioned to respect Sad and Sat Guru; 5) Beji as a place to clean up ourselves before doing a devotion; 6 Graha Guru as a place to welcome and sublime Sad and Sat Guru; 7: Linggam Siva, Ganesha, and Hanuman as a central point of devotion; 8) Mandala as a Gods Siva's shakti symbol which is spread out to all corner. This place functioned as a place for meditation, japa, and the other special activity. One of those linggams is as shown in the picture below.

Picture 1. Sri Nandini

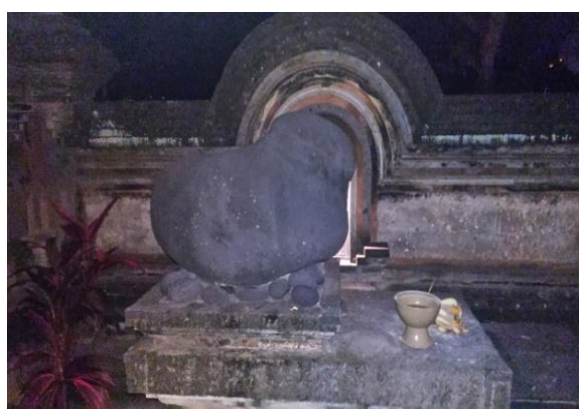

Documentation I Made Arsa Wiguna, 2017

Vrata Vijaya Ashram is well managed and the managements are as follow:

a. Maha Guru: Maha Guru Sri Jaya Nara (Wayan Sujaya, S.Ag); b. Spiritual teacher/Acarya: Sri Hasta Dala (Drs. Ketut Murdana, M.Si)

c. Head of Asram: Drs. Dewa Putu Mertha, M.Si

d. Deputy Head of Ashram: Made Mahardika

e. Secretary: Gede Sudarpa

f. Treasurer: Gede Arda

g. Main Members:

Komang Suriadi

Ida Bagus Astawa

Agung Putri

Ni Ketut Suriani

Ni Luh Sukiartini

The other members are around 240 people

Source: Secretary of Ashram

\subsection{Form of Sin Abolition in Siva Puraana's Text}

Sin abolition in Siva Puraana's text is written in short holy text (sloka) and become an interesting story ie:

a. Glory of Sivaratri

b. Vedanidhi

c. Yama's Obligation

d. Result of Mentioning God's name (Siva)

e. Ganesha's birth

f. The greatness of Mahabala

g. Achieving a good goal by women outside the caste

h. The greatness and glory of Mahabala

i. The Greatness of the other Siva's Lingga

j. Siva Puraana in Rudra Samhita part I Chapter I.38 (The Greatness of Siva Puraana)

k. Chapter IV.37, 38, 44, 46, 49, 50, 51, 52, 53, 59, 60, 71 (Narada went 
to Vaikunta dan come accross Visnu over there)

1. Chapter VI.2 (Description of Mahapralaya's Character and who is Visnu actually)

m. Chapter XVIII.24 (Redemption of mistakes from Gunanidhi)

n. Siva Puraana in Rudra Samhita part II Chapter VI.1 (Praise sung by Sandhya and Sandhya get the grace from Siva)

o. Chapter XX.38 (Wedding of Siva and Sati)

p. Chapter I.10, 13, 15, 16, 17, 23, 25, 38, 42, 45 (The Greatness of Siva Purana)

q. Chapter II.1, 2, 5, 6, 13, 37, 39-40 (Liberation of Devaraja)

r. Chapter IV.1, 15, 40 (Liberation of Cencula)

s. Chapter V.50 (Liberation of Binduga)

t. Siva Puraana in Vidyesvara Samhita Chapter II.2, 3, 4, 20, 23, 36, 40, 43, 45 (The Answer that Given To Answer the Doubt of the Rsi)

u. Chapter V.3, and 31 (The Greatness of Siva Lingga Siva Lingga)

v. Chapter VIII.18 (Forgiveness of Siva to Brahma)

w. Chapter IX.20, 26, 34 (Inauguration for Siva as Mahesvara)

x. Chapter X.37 (The disappearance of Siva after explaining the five obligations of God, and the Omkara mantra on Brahma, and Visnu) y. Chapter XI.19, 58 (The way to Praise Linggam and create an offerings)

z. Chapter XII.14 (An explanation about various temples of the Gods Siva)

aa.Chapter XIV.44 (An explanation about the holy fire ceremony/ agnihotra)

bb. Chapter XV.32 (An explanation about terms, time, and place for conducting Devayajna and others)

cc.Chapter XVI.43, 63, 64, 67, 113, 115 (Someways to worship Gods Statue and the result)

dd. Chapter XVII.11, 53, and 147 (The Greatness of Om syllables and five syllables mantra)

ee. Chapter XVIII.148, 149, 162 (The nature of bonding, and liberation, and the majesty of Siva)

ff. Chapter XIX.19, 20, 21 (The Greatness of Worship To The Siva Lingga Statue Made of Clay)

gg. Chapter XX.42, 43, 64, 65 (The Way to Worship Lingga Statue Made of Clay by Saying Vedic Mantra)

hh. Chapter XXII.13, 18, 27, 28, 29 (The rule of sharing Naivedya Siva with others, and the Grandeur of the Bilva Tree)

ii. Chapter XXIII.6, 7, 10, 11, 14, 15, 17, 22-24, 27-31, 35-37, 39, 41-44 (The Greatness of Rudhraksa Tree abd Siva's Name)

jj. Chapter XXIV.19, 20, 51, 52, 53, 55, 56, 76 (The Greatness of Hoky Ashes) 
kk. Chapter XXV.9, 19, 32, 48, 54, 64, 66, 70, 71 (The Greatness of Rudhraksa Seed)

11. Siva Puraana in Rudresvara Samhita Parvatikhanda Part III Chapter I until LV. Start form Chapter I.3, 23 and 24 (Himacala's Wedding)

mm. Chapter III.5 (Praise that offered by Visnu and the other Gods)

nn. Chapter IV.49 and 50 (Mahadewi is Entertaining the Gods)

oo. ChapterVI.52 (Parvati's Birth)

pp. Chapter VIII.49 (Conversation between Naradha and Himalaya)

qq. Chapter XXI.35 and 36 (Narada Teaches Parvati about Tapasya)

rr. Chapter XXIV.73 (Siva Agree to Married with Parvati)

ss. Chapter XXIX. 2 (Dialog between Siva and Sakti)

tt. Chapter XXXIX. 2 (The Gods Arrive at Kailas Attending Siva's Invitation and Siva Starting the Preparation)

uu. Chapter XLII.31 (Story is Telling about the Meeting between Siva and Himawan)

vv. Chapter XLIV.97 (Mena Regained Consciousness)

ww. Chapter XLV. 8 (The appearance of Siva which is very handsome and the whole people are happy)

xx. Chapter LIV. 72 and 78 (An Explanation abput Obligation of a Holy Wife)

yy. Chapter LV. 31-34 (Siva Back to Kailas)

zz. Chapter I.7 (Loving Game of Gods Siva) aaa. Chapter XI.31-33 (Kumara's Victory and Death of Bana and Pralamba)

bbb. Siva Puraana in Rudra Samhita Yudha Kanda Part V Chapter I until LIX. Start from Chapter III. 42 and 54 (Tripura's Virtue)

ccc. Chapter IV.35 (Tripura's Initiation)

ddd. Chapter XI. 4 (Prayers of the Gods)

eee. Chapter XXV. 21, 27, 35, and 36 (Prayers of the Gods)

fff. Chapter XXVI. 57, 58, and 61 (The disappearance of Gods Visnu's Illusion)

ggg. XXVII. 3 (Sankhacuda's Birth) hhh. Siva Puraana Chapter LVI.28 (Bana Sura is Achieving Position as Gana of Gods Siva)

iii. Chapter LVII. 66, 67, and 73 (The Killing of Gaja Sura)

jjj. Chapter LVIII. 47 and 50 (The Killing of Dundubhi Nirhrada)

kkk. Chapter LIX. 40 (The Killing of Vidala and Utpala)

\subsection{Comprehension of Hindus in Denpasar City about Siva Puraana's Text}

Historically, Purana began to flourish in the era of Hindu renaissance in India (Mahajan and Majumdar inside Phalgunadi, 2013: 39). Then Titib (2004: 14 explained that etymologically Puraana comes from the word pura meaning ancient, and ana meaning to say. Puraana is defined as an ancient history that tells the birth and life of the Gods, kings, and Rsi. Each puraana story essentially contains religious education. 
Similarly, described by Sivananda (2003: 26), that Puraana in general aims to popularize the religion of the Vedas, which contain the essence of Vedic teachings. The goal is to cram the minds of the layman about the Vedic teachings and to awaken their devotion to God through concrete examples, myths, stories, legends, the lives of saints, kings and great men, figurative stories and the historical sequence of major events. The wise use this to describe the principles of eternal religion.

Correspondingly, Saraswati (2009: 251), describes the Puranas as the "Magnifying Glass" of the Vedas because they enlarge the small images into big drawings. The Vedic teachings listed in small statements that are enlarged and elaborated in the form of stories or anecdotes within the Puranas.

Siva Puraana is one of 18 Mahapuraana which describes the majesty of Siva and Lingga. The book of Siva Puraana consists of 7 Samhita namely Vidyesvara, Rudra, Satarudra, Kotirudra, Uma, Kailasa, and Vayaviya

The glory of Siva Puraana as stated by Sanjaya (2010: xv), that Siva Purana was honored as a great Puraana because of its contents explaining the ritual of Siva worship. This Puraana perceived Siva as the eternal principle, the supreme god, cosmic soul, and the buffer of the universe.

Broadly speaking, there are three ways to achieve liberation (attaining union with Siva) namely:

a. Sravana or imagine and meditate on his sacred name, listening to all the stories, words of praise related with Siva in any way, anywhere, that will always produce a fascination more than the attractiveness of a woman. Sravana also will be effective if someone joins in a collection of saints.

b. Kirtana is expressing the greatness of Siva, his attributes, being, his name, etc., in a holy way by telling the story of his greatness, singing hymns of praise to him, even by using the language in daily life.

c. Manana is a meditation on his form. If all of these ways happen, then Sivayoga or union with Siva will be achieved. But not everyone can do that, so there is an easier way to reach the liberation itself. In Siva Puraana Chapter V.1-17, it is explained that the person who is unable to perform the three prescribed rituals to attain liberation, should make a Siva Lingga, and worship him daily. Lord Siva is worshiped with his phallus and his own form.

Based on the observations in the Vrata Vraya Ashram, worship is done periodically every month, the $7^{\text {th }}$ is the worship of Ganesha, the $10^{\text {th }}$ worship of Bhatara Siva, the $13^{\text {th }}$ worship of Mother Parwathi, and the $27^{\text {th }}$ worship day of the teacher. The means used are: pejati, accompanied by bungkak gading or the other means at best. Generally the devotees in the ashram has a good comprehension of the worship to Siva and his manifestation. It can be seen from the explanation of Dewa Putu Merta (Interviewed on August $10^{\text {th }}, 2017$ )

"Siva Puraana is about the life of God (Siva). The meaning of Siva in this case that is according to the concept of Tri Purusa (Parama Siva that cannot be imagined, Sada Siva in its manifestation as Tri Murti i.e. Brahma Vishnu and Siva, 
that gives life to the universe and its contents).

Another statement came from Gede Sudarpa who's also one of the ashram's devotees and managers (interviewed on August $10^{\text {th }}, 2017$ ):

"I like to read Siva Puraana including the dharmawacana collection of the Grand Master and believe in the content of it. I like God Siva because He is not tied to worldly treasures seen from His appearance that does not use gold and other jewelry. In general, the content of the Siva Puraana text is about the life and lila of God Siva. The reading of some sloka from Siva Puraana in Vrata Wijaya ashram was done at the time of Siva worship on the $10^{\text {th }}$ followed by the explanation of the sloka by Guru Sri Hasta Dala, so that the devotees understand the intent of it. The reading was done in the front of Guru Sri Hasta Dala and the devotees".

In line with the teachings of Siva Puraana, there are three main ways to attain liberation or unification with Siva: 1) Sravana; 2) Kirtana; and 3.Manana. These three ways have been done in Vrata Vijaya Ashram as well. Sravana with the recitation of Siva Puraana at the time of Siva worship on the 10th of each month, listening to the majesty of Siva, the words of praise for Siva, the body posture in reciting the praise through the reading of Siva Puraana is the form of Sravana's application. Then Kirtanam that is by singing praises to Siva like one of song called Swari Sundaram which aims to glorify the soul, glorify the greatness of the beautiful, liberate the worldly bonds, namely satwam, rajas, tamas. Manana is done with meditation while repeating the holy name of God Siva.
The worship of Siva is also done by making Siva linga along with His manifestations, and the worship of Siva is also accompanied by a dance that aims to worship and glorify Siva and His aspects.

Anggre (interviewed on August $3^{\text {rd }}$, 2017 gave a statement as follows:

"I only have a few books of Siva Puraana, and read it not too often, only in my spare time. I am interested in reading Siva Puraana to know how to worship Siva. The essence of His teaching is about how to live life and the achievement of life (heaven and hell). By reading Siva Puraana, I get the benefit of the ordinance guidelines for living in the world. Related to the ethics in the reading of Siva Puraana, I see that the Siva Puraana can be read everywhere as long as it is comfortable, it is also deppend on the reader's own atmanastuti (peace of mind). The rules in reading Siva Puraana must be considered in order to get benefit by reading it. In my opinion, anyone can read it, beside its essence, Siva Puraana also contains moral teachings. In Siva Puraana, the devotion is directed to God Siva, but it is only as a perception that helps to understand the essence contained"

Similarly, Saputra as a student at one of the Hindu universities in Denpasar City stated that he did not have Siva Puraana but sometimes took the time to read Siva Puraana. According to him, in each Puraana, it glorifies each Gods who is considered to have everything, but basically in the teachings of Hinduism all the Gods are honored as a manifestation of Brahman or Ida Sang Hyang Widhi Wasa in accordance with own function, so to learn and understand the essence of Brahman (Ida Sang Hyang Widhi Wasa) and 
all His manifestations, we should read and study about Puraana, including Siva Puraana which essentially teaches about the majesty and omnipotence of God Siva. The benefit of studying Siva Puraana according to him is by doing any positive deeds according to the teachings of Siva Puraana, will definitely get a positive reward as well.

Related to the ethics of reading Siva Puraana, according to him, it could be read anywhere because knowledge cannot be limited by space and time, but of course, there are rules that must be followed in reading Siva Puraana. It is based on the sloka in Sarasamuccaya, which states that the Vedas are afraid of people with little knowledge so that it is very important for anyone who wants to read Siva Puraana to pass the Pawintenan Saraswati (Sanctification) process as a form of niskala (unseen circumstances) cleansing.

One of the academics at Denpasar Higher Education, Widyasena, has a different understanding of Siva Puraana as follows:

"By reading Siva Puraana, I know about the majesty of God Siva, and as I know, Siva Puraana consist of the three things that is about the majesty of Siva as the ultimate reality, the creation of the universe and the way of reaching Siva. By reading Siva Puraana I can open my heart to continue to be good with sincere caring towards others and the environment. Related to the ethical reading of Siva Puraana, that can be read anywhere, as long as the place is clean and holy. Before reading Siva Puraana, someone should perform the Siva puja with namasmaranam Siva, such as $\mathrm{Om}$ Namah Sivaya's mantra, Sivoham and other Siva Mantra and ending also with Siva Namasmaranam and meditation so that the Puraana's reading is always blessed and could be implemented in daily life. Basically, everyone can read Siva Puraana. In Siva Puraana, the bhakti's form of the people to God is the majesty of God Siva. I think it is normal because by reading and listening to Puraana we are taught to strengthen our sraddha (belief) against the path we choose according to our heart".

\subsection{Hindus Perception in Denpasar City about the Abolition of Sin in Siva Puraana's Text}

Siva Puraana explains the majesty and journey of Lord Siva, also describing the various forms about the abolition of sins which are contained in the form of sloka. As explained on the previous chapter, the abolition of sins can be done only by listening or reading Siva Puraana, even a brahmana who does not perform his obligation as well, his sin was wiped out by listening to Siva Puraana's recitation. By reading this Siva Puraana, someone will be free from sins. After enjoying all the worldly pleasures then will reach Siva's palace.

It is only by listening to Siva Puraana's recitation, someone has benefited as well as the implementation of Rajasuya and Agnistoma. Those who listen to Siva Puraana will become a nobleman, surely could be considered as a manifestation of Rudra, one of Siva's manifestations. Someone who wants liberation is suggested to listen to that sacred Siva Puraana with great adoration. If someone does not have enough time to listen to Siva Puraana on a daily life, so that could listen to it in certain holy months.

Someone who listens to Siva Puraana's recitation, even if only 48 minutes, 
or half of that time, even a quarter of that time, or even a moment, will not get hurt. The house where the texts of Siva Puraana are kept will be sacred. He can destroy the sins of the inhabitants of the house. A sinner remains sinful until hears Siva Puraana with great worship.

Related to the abolition of sin according to Sudarpa (interviewed on August $\left.10^{\text {th }}, 2017\right)$, it can only be done by doing good because it can compensate for the sins that have been done. The existence of the story about the abolition of $\sin$ in the text of Siva Puraana according to him, aims to improve sradha (believes) and bhakti of Hindus especially Siva worshipers. The teachings of Jnana Buda Siva taught in this ashram aims to increase the understanding of the attributes of God, knowing that God exists within and outside of self that raises the ministry to oneself and others, and of course, this can erode slowly the sins ever committed by not repeating them.

Meanwhile, according to Guru Sri Hasta Dala (interviewed on July $23^{\text {rd }}, 2017$ ), the word for the removal of $\sin$ in the Siva Puraana text should not be misunderstood. The sin actually cannot be wiped out, but the sinful man has indeed enjoyed his bad karma through the events that afflict him or the problems in his life and will be cleansed of his thoughts, words, and deeds by reading and understanding the teachings of Siva Puraana. If reading Siva Puraana without practicing it, then the result is less than maximum. At Vrata Vijaya Ashram, Siva's teachings are not only understood but well-practiced, so that devotees get positive benefits from such worship such as increasing concentration, adding feelings about and being peaceful, being able to control emotions, to be healthier and of course to be a better person. Therefore, it will not repeat the same sin because it has understood and practice the teachings of Siva directly. It added that holy knowledge, karma jnana, fasting, and self-control are the keys to liberation. Mother is a person who should be glorified according to Siva Puraana because the mother will protect and love. Doing puja will reach the union between Atman with Paramatman, sukha tanpa wali dukha. When souls have risen by knowing the sacred knowledge then the souls will know the Soul of the Great.

Widyasena has a different perception about sin abolition in Siva Puraana (interviewed on September $2^{\text {nd }}, 2017$ ), he states that similar with the any other Puraana, Siva Puraana can wipe out all the sins committed by a man as in the story of Chencula who saved her husband and in the story of Dewaraja in Siva Puraana. Someone will be forgiven even if he only reads and listens to just a little bit of Siva Puraana, but it would be even better if the truthful and good doctrine implied in Siva Puraana can also be well implemented in daily life. Further, according to Widyasena, all sins can be wiped out by worshiping Siva, because the teachings of religion and God are a form of human belief in His majesty. The abolition of $\sin$ in Siva Puraana as proof of Siva's form of power as the ultimate reality can bring happiness and strength in breaking away from earthly bonds and destroying sin. In principle, almost all human actions are based on their belief in an object. Similarly, with Siva's blessing as the ultimate reality, if belief in Siva can wipe out all sins committed and give happiness, then it will happen. Like a child who trusts his father to give him happiness. 
Merta (interviewed on August 10 ${ }^{\text {th }}$, 2017) states that reading Siva Puraana may not necessarily eliminate sin, its teachings must be understood and implemented in order to reduce or cover up the sins ever committed. If humans are able to perform the puja (devot) as well then it can be said to be able to control the worldly bonds. In this Kali Yuga a sincere puja will lead someone to liberation.

Similarly, Anggra (Hindu's highscool student) states that sin cannot be abolished, but can be balanced by doing yadnya (sincere sacrifice) and worship of Siva. Similarly, Saputra (Hindu's highscool student) states the same thing that sin is very easy to do but still cannot be wiped out, but even the smallest good deeds can erode sins ever committed before. Similarly, Septyawan (private employees) who claim that $\sin$ can be accumulated with good deeds such as doing tapa, brata yoga, semadhi.

While Maha Putra gave a different opinion as follows:

"For the issue of the sin abolition, this is something that can be said to be impossible because we are exposed to karmaphala and punarbhawa, which is a universal law so that $\sin$ is not abolished but we must balance with good deeds. If viewed from Siva Puraana, maybe by worshipping and japa, we can balance the sin and more awakened to the mistakes ever made so that the sins increasingly marginalized with good deeds that exist. The abolition of sin only by worshiping Siva is not impossible but it is a difficult thing, because every human who has been born carries their own karmawasana (former deeds), so the concept of the abolition of sin, in my opinion, is the process of balancing bad deeds with good deeds, so that good deeds become more dominant, but whatever it is, if Siva deign it, then it will be possible".

Adi Brahman, one of the academics at the Hindu college in Denpasar, affirmed that worshiping Siva is also a form of karma. Each karma will certainly bring a phala (result of karma or act), so that between worshiping Siva and the abolition of sin does not contradict the law of karmaphala (the law of cause and effect in Hindu's term).

Most of the results of the interviews indicate that sin cannot be simply abolished, but by reading, understanding and applying the teachings of Siva Puraana as well, the sins will be able to be balanced with good deeds. In addition, it can be understood that by reading the greatness of Siva, it will be able to increase sradha (believeness) and bhakti (worship) of Hindus especially those who read well and accompanied by spiritual teachers, so that the teachings contained in the text of Siva Puraana is not misinterpreted.

\section{Conclusion}

Some citations of the story and sloka about the abolition of sin in the Siva Purana text include: Glory of Sivaratri, Vedanidhi, Yama's obligation, result of mentioning God's name (Siva), Ganesha's birth, the greatness of Mahabala, Achieving a good goal by women outside the caste, The greatness and glory of Mahabala, The Greatness of the other Siva's Lingga. In addition, there is also a series of sloka on some Samhita in Siva Puraana which states about the abolition of sins.

The understanding of the Hindus in Denpasar City on the Siva Puraana text is relativelly good, due to the content of Siva Puraana was implemented as well especially in Vrata Vijaya Ashram which specializes in 
glorifying Siva and His manifestations. The three paths to liberation and unification with Siva ie Sravana, Kirtana, and Manana are properly applied in the ashram. Hindus in other cities of Denpasar also understand that Siva Puraana contains teachings about the glory and majesty of Siva and guidelines for behaving according to the teachings of Siva.

Perceptions of Hindus in the city of Denpasar, especially in Vrata Vijaya Ashram and other Hindus including students and academics at Hindu colleges in the city of Denpasar showed that mostly have similar thoughts. Sin is basically indestructible only by listening to the reading of Siva Puraana and reading it at a glance but must be balanced with a strong conviction and instill goodness sourced from the Siva Puraana text into each one. So that the sins that have been done before do not happen again. The real sin has been redeemed by accepting the phala from bad karma as a living through the various problems of life, and if studying about Siva Puraana, understand and apply the teachings in Siva Puraana, they will undoubtedly gain a better life.

\section{References}

Bhandesa, A. M., Suyasa, I. G. P. D., \& Darmapatni, N. W. K. (2017). The Educational Value of Hinduism on the Gumi Suda Ceremony at the Birth of the Twin Babies with Different Genders (Case Study at Pakraman Village of Ketewel, Sukawati District, Gianyar Regency). Vidyottama Sanatana: International Journal of Hindu Science and Religious Studies, 1(2), 93-102.

Ginarsa, Ketut. 2002. Atma Prasangsa. Denpasar: CV Kayumas Agung.
Kajeng, I Nyoman. 1999. Sarasamuccaya. Surabaya: Paramita.

Murdana, I Ketut. 2016. Pancaran Kedamaian Refleksi Jnana bUda Siwa. Surabaya: Paramita

Murdana, I Ketut. 2014. Jnana Budda Siwa Pengalaman Spiritual Bersama Guru. Surabaya: Paramita

Nasution, S. 2014. Metode Research

Penelitian Ilmiah) Usul Tesis-Desain Penelitian-Hipotesis Validitas-

Sampling-Populasi-Observasi-

Wawancara-Angket

Netra, Anak Agung Oka. 2009. Tuntunan Dasar Agama Hindu. Denpasar: Widya Dharma.

Phalgunadi, I Gusti Putu. 2013. Sekilas

Sejarah Evolusi Agama

Hindu.Denpasar: Program Magister (S2) Ilmu Agama dan Kebudayaan Universitas Indonesia bekerjasama dengan Penerbit Widya Dharma.

Pudja, G. 2003. Bhagawadgita (Pancamo Weda). Jakarta: Pustaka Mitra Jaya.

Pudja, G. dan Tjokorda Rai Sudharta. 1976.

Manava Dharma Sastra. Jakarta: CV. Junasco Rampan, Korrie Layun. 2014. Teknik Menulis Cerita Rakyat. Bandung: Yrama Widya.

Sanjaya, Gede Oka. 2010. Siva Puraana Vol.I. Surabaya: Paramita.

Sanjaya, Gede Oka. 2011. Siva Puraana Vol.II. Surabaya: Paramita.

Saraswati, Sri Chandrasekharendra. 2009.

Peta Jalan Veda. Media Hindu.

Sivananda, Sri Svami.2003.Intisari Ajaran Hindu. Surabaya, Paramita.

Sivananda, Sri Svami.2005.Apa yang Terjadi pada Jiwa Setelah Kematian. Surabaya: Paramita. 
Sripakdee, P. P. (2017). The Role Of

Buddhist Ethics And Communication

In The Contemporary World Crisis.

Vidyottama Sanatana: International

Journal of Hindu Science and

Religious Studies, 1(2), 155-159.

Suamba, IBP. 1999. Siwa Sahasra Nama

(Seribu Nama Siwa) dalam Siwa

Puraana. Denpasar: Yayasan Dharma

Sastra

Sudharta, Tjok. 2003. Slokantara Untaian

Ajaran Etika Teks, Terjemahan dan

Ulasan. Surabaya: Paramita

Sugiono. 2009. Metode Penelitian

Pendekatan Kuantitatif Kualitatif dan

$R \& D$. Bandung: Alfabeta.

Suhardana, K.M. 2006. Memaknai

Kesejagatan Hindu.. Denpasar, PT. Empat Warna Komunikasi.

Titib, I Made. 1996. Veda Sabda Suci Pedoman Praktis Kehidupan.

Surabaya: Paramita.

Titib, I Made. 2004. Purana, Sumber Ajaran

Hindu Komprehensip. Surabaya:

Paramita.

Titib, I Made. 2007. Teologi Hindu (Brahmavidya) Studi Teks dan Konteks Implementasi. Bahan Ajar (tidak diterbitkan). IHDN Denpasar.

Wijaya, A.A. Ngr. Prima Surya. 2011. Siva Puraana Vol III. Surabaya: Paramita

Wiguna, I. M. A. (2018). KEUTAMAAN SIVA PURAANA (Senjata Ampuh Penghancur Dosa). 